\title{
EFFECT OF POMEGRANATE (Punica granatumL.) FRUITS PEEL ON SOME PHYTOPATHOGENIC FUNGI AND CONTROL OF TOMATO DAMPING-OFF \\ Tahany.G.M. Mohamad ${ }^{1}$ and Amal.A.Khalil ${ }^{2}$ \\ 1 Central Agricultural Pesticides Laboratory, Agriculture Research Center. Giza, Egypt. \\ 2 Plant Pathology Research Institute. Agriculture Research Center. Giza, Egypt
}

\begin{abstract}
Pomegranate peel powder and its extract were used to study their efficiency against damping-off disease caused by Fusarium oxysporum f. sp. lycopersici. In vitro, methanolic extract of pomegranate peel caused inhibitory effect to the linear growth of different phytopathogenic fungi isolated from different hosts including:

Botrytis cinerea, Colletotrichum dematium, F. oxysporum, F. solani, Phoma sp. and Rhizoctonia solani. Also, Pomegranate peel extract (PPE) effectively decreased linear growth and spore germination of $F$. oxysporum and greatest decrease was recorded at $4000 \mathrm{ppm}$ under greenhouse conditions. Application of pomegranate peel powder as seed treatment or soil treatment deceased pre and postemergence damping-off caused by $F$. oxysporum f. sp. lycopersici compared with untreated infected control. Treating tomato seedlings or soil with peel extract before sowing provided a good protection against damping off and soil treatment was more effective than seedling treatment. Methanolic extract of pomegranate peel revealed that it contained different compounds of antifungal activity including three flavonoids, three tannins, four phenolic compounds, one glycosides along with four sterols.

Keywords: Fusarium oxysporum f. sp. lycopersici, Linear growth, spore germination, Gas chromatography-mass spectrometry ( GC-MS)analysis, antifungal activity,flavonoids, tannins, phenolic compounds, glycosides, sterols.
\end{abstract}

\section{INTRODUCTION}

Tomato (Lycopersicon esculentum Mill) is one of the most economic vegetable crops cultivated at different locations in Egypt and all over the world for either local consumption or export purposes (Tampoare et al., 2013). It is subjected to attack by many soil borne fungal diseases specially the damping-off and wilt diseases causing considerable losses either in nurseries or in the field (Abdel-Kader et al., 2012). Farmers usually apply synthetic fungicides as preventive and therapeutic measures to control plant diseases, though the hazardous effect for the environmental pollution (Steffens et al., 1996 and Ishii, 2006) and the risk of pathogenic microorganisms (Barnard et al., 1997 and Brent and Holomon, 1998).

Recently, certain natural products of plant origin have been evaluated as a source of antimicrobial agents against a variety of phytopathogenic fungi (Dahham et al., 2010, Al-Askar 2012 and Mangang and Chhetry 2012).

The extract of peel, seed and whole fruit of pomegranate (Punica granatum L.) have antimicrobial activity against many pathogenic fungi and bacteria in vitro and in vivo (Dahham et al., 2010 and Al-Askar, 2012. In this 
respect, Dahham et al., (2010) and Sadik and Asker (2014 ) identified different compounds which have antimicrobial activity from various parts of pomegranate fruit, including phenols, flavonoids, condensed tannins, hydrolyable tannins and polyphenols. In searching for compounds from plants that are active against plant pathogenic fungi, we found that the methanol extract of pomegranate peel is highly active against most of plant pathogens tested. So, the aim of the present study is to evaluate the anti-fungal activity of methanolic extracts of pomegranate peel against the phytopathogenic fungi So, the present study aimed to evaluate the antifungal activity of pomegranate peel extract against some phytopathogenic fungi as well as its effect on the linear growth, spore germination of $F$. oxysporum f. sp. lycopersici, to control tomato damping-off. Also, phytochemical analysis to pomegranate extract using GC-Ms technique was carried out.

\section{MATERIALS AND METHODS.}

Preparation of methanolic extract of pomegranate peel:

Fresh fruits of Pomegranate (Punica granatum L.) were manually peeled. The collected peels were then rinsed with distilled water and dried in an oven at $\left(50^{\circ} \mathrm{C}\right)$ for $48 \mathrm{~h}$, and were powdered to get 60 -mesh size using a mixing grinder (Dahham et al., 2010). The powdered peels $(2 \mathrm{~g})$ of pomegranate were macerated with $20 \mathrm{ml}$ of $80 \%$ methanol at room temperature. The macerated material was strained through Whatman No1 filter paper. The extract was concentrated at $40^{\circ} \mathrm{C}$ by using Rotary Evaporator (Heidolph, LABOROTA A 4000 -Germany) then dried in the oven at $50^{\circ} \mathrm{C}$ for 48h. Finally, by using the dried extract, different concentrations of methanolic extract i,e $31.3,62.5,125,250,500,1000,2000$ and 4000 ppm were prepared (Tayel et al., 2009).

\section{Phytopathogenic fungi used}

Six authentic phytopathogenic fungi isolated from different hosts, were used in this study. Botrytis cinerea (pea), Colletotrichum dematium from (soybean), F. oxysporum, F. solani, Phoma sp. and Rhizoctonia solani from (tomato). Kindly were provided by Seed Pathol. Res. Dept., Plant Pathol. Res. Instit., ARC. The tested fungi were regularly subcultured and maintained on potato dextrose agar (PDA) medium in a refrigerator at 5 $\pm 1^{\circ} \mathrm{C}$, throughout the course of the study.

Effect of (PPE) on the linear growth of some fungi.

The anti-fungal activity of methanolic extract of pomegranate peel was studied in vitro by a poisoned food technique (Singh et al., 2008). PDA medium was autoclaved and the methanolic extract was added after reasonable cooling to 30-35 $\mathrm{C}$ and vigorous shaking along with one $\mathrm{ml}$ of streptomycin before pouring into Petri-dishes, The prepared concentrations of methanolic extracts were i,e $0.0,31.3,62.5,125,250,500,1000,2000$ and 4000 ppm were added to PDA medium and then poured into three Petri-dishes. Petri-dishes contained PDA medium only were used as control. A disc (4 mm diameter) of any of the six fungal species, i,e $B$. cinerea, $C$. dematium, $F$. oxysporum, $F$. solani, Phoma sp. and $R$. solani was cut from 1-week-old culture and inoculated to the 
center of the poured plates. Plates were sealed with Parafilm then incubated. Three replicates were used for each treatment at $25 \pm 2{ }^{\circ} \mathrm{C}$ until the fungal growth in the control dishes was almost completed (Agarwal et al., 2001).

Effect of (PPE) on the linear growth of $F$. oxysporum f. sp. lycopersici:

One $\mathrm{ml}$ from each concentration of PPE (250, 500, 1000, 2000 and 4000 ppm) was mixed with reasonably cooled PDA medium and then poured in Petri-dishes. Plates containing only PDA medium were used as control treatment. All plates were inoculated with discs of 8 days old culture of $F$. oxysporum $F$. oxysporum and then incubated at $25^{\circ} \mathrm{C}$. When the mycelial growth covered the whole surface in the control plates, the linear growth in different treatments was determined. Three replicates were used for each concentration. The decreased percentage in mycelial growth of $F$. oxysporum $F$. oxysporum was calculated using the following formula:

Where:

$$
\text { Percentage of inhibition or fungal growth }=\left(\frac{C-T}{C}\right) \times 100
$$

$\mathrm{C}=$ Fungal growth of the control.

$\mathrm{T}=$ Fungal growth of the treatment.

Effect of PPE on spore germination of $F$. oxysporum f. sp. lycopersici:

Different concentrations of PPE (250, 500, 1000, 2000 and 4000 ppm) were tested. One drop from spore suspension of $F$. oxysporum $F$. oxysporum was added to the mentioned concentrations were pipetted by sterilized pipette on glass slides. Other glass slides, with drop from spore suspension, were prepared using distilled water as control treatment. All slides were incubated at $25^{\circ} \mathrm{C}$ for $18 \mathrm{~h}$. Three replicates were used for each concentration. Percentage of spore germination was recorded after microscopic examination and percentage of inhibition in germination was calculated as mentioned before.

Assessing of $\mathrm{EC}_{50}$ :

$\mathrm{EC}_{50}$ values were determined by the linear regression ( $\mathrm{LPd}$ line Computer Program) of the probit of the tested fungus percentage inhibition vs. logs the concentrations (ppm) of the tested extract. The $\mathrm{EC}_{50}$ notation used to indicate the effective concentration (ppm) that causes 50\% growth inhibition.

Greenhouse experiments:

Preparation of fungal inoculum:

Corn meal-sand medium $(3: 1 \mathrm{w} / \mathrm{w})$ in $500 \mathrm{ml}$ glass bottles was autoclaved at $121^{\circ} \mathrm{C}$ for 30 minutes. The sterilized bottles were then inoculated with discs (5 $\mathrm{mm}$ in diam.) of 8 days old culture of $F$. oxysporum and incubated at $25^{\circ} \mathrm{C}$ for 15 days. Fungal inoculum of $F$. oxysporum was mixed thoroughly with the potted sterilized soil at the rate of $4 \%$ inoculum level $(\mathrm{w} / \mathrm{w})$. The infested soil was adequately watered for one week to enhance growth and distribution of the fungal inoculum. 
Effect of tomato seed treatment and soil application with pomegranate peel powder on the incidence of pre and post- emergence damping-off caused by $F$. oxysporum f. sp. lycopersici.

a- Seed treatment

Tomato seeds (Beto ,cv) were treated with Arabic gum (1\%) as a sticker and then coated with pomegranate peel powder at the rate of $10 \mathrm{~g} / \mathrm{kg}$ seed. Another group of seeds was treated with the fungicide Flowsan $42.7 \%$ FS at the rate of $3 \mathrm{~g} / \mathrm{kg}$ seed. Untreated seeds were used as a control treatment. Then seeds were sown in pots $(30-\mathrm{cm}-$ diam.) containing soil infested with $4 \%$ inoculum level of $F$. oxysporum f. sp. lycopersici. Six seeds were sown in each pot and four replicates were used for each treatment.

\section{b- Soil treatment:}

Pomegranate peel powder was added to pots (30-cm-diam) containing soil infested with $4 \%$ inoculum level of $F$. oxysporum at the rate of $100 \mathrm{~g} /$ pot, and then the pots were transplanted with untreated tomato seedlings at the rate of 6 seedlings per pot. Four replicates were transplanted in each pot. The growing seedlings in all treatments were examined periodically. Pre and post emergence damping-off was recorded 15 and 30 days after transplanting.

Effect of tomato seedling treatment and soil treatment with pomegranate peel extract on disease incidence.

Seedling treatment:

Four-week old tomato seedlings were dipped in PPE (4000 ppm) for $1 \mathrm{~h}$. Other seedlings were dipped in the fungicide Rizolex $\mathrm{T} 50 \%$ at the rate of $3 \mathrm{~g} / \mathrm{L}$. Untreated seedlings were used as control treatment. The seedlings were transplanted in pots containing soil infested with $4 \%$ inoculum level of $F$. oxysporum. Six seedlings were transplanted in each pot and four replicates were used for each treatment.

Soil application:

Pots (30 cm-diameter) containing soil infested with $4 \%$ inoculum level of $F$. oxysporum f. sp. lycopersici were treated with pomegranate peel extract (10 $\mathrm{ml} / \mathrm{pot})$, Transplanting was made with uninoculated 4-week-old tomato seedlings. Six Trans plants were sown in each pot and four replicates were used, plants in all treatments were examined periodically and the disease incidence 60 days after transplanting was recorded.

Phytochemical analysis of PPE:

The preliminary Qualitative phytochemical for the presence of various phytochemical compounds was performed using the methanolic extract. Presence of carbohydrates was determined by Molish's test. Presence of reducing sugar was detected by Benedict's test. (Ramkrishnan and Rajan 1994). Alkaloids in the extract were evaluated by Mayer's test. The sterols and Glycosides were determined by Salkowski's test and Borntrager's test, respectively. (Evans 1997). The saponins were analyzed by Froth's test (Kokate, 1999). The occurrence of phenolic compounds and tannins were confirmed by ferric chloride and gelatin tests, respectively (Mace, 1963). The presence of flavonoids was investigated by lead acetate test (Kosalec, et al., 2005). 


\section{GC-MS Analysis of PPE:}

The qualitative and quantitative compositions of the methanolic extract of pomegranate peel extract were studied by GC-MS analysis Agilent 6890 gas chromatography (equipped with an Agilent mass spectrometric detector, with a direct capillary interface and fused silica capillary column PAS-5 ms, $30 \mathrm{~mm} \times 0.25 \mu \mathrm{m}$ film thickness). Samples were injected under the following conditions: Helium was used as carrier gas at approximately $1 \mathrm{ml} / \mathrm{min}$., pulsed split less mode. The solvent delay was 3 minutes and the injection size was $1.0 \mu \mathrm{l}$. The mass spectophotometric detector was operated in electron impact ionization mode an ioning energy of 70 e.v. scanning from $\mathrm{m} / \mathrm{z} 50$ to 500 . The ion source temperature was $230^{\circ} \mathrm{C}$ and the quadruple temperature was $150^{\circ} \mathrm{C}$. The electron multiplier voltage (EM voltage) was maintained $1250 \mathrm{v}$ above auto tune. The instrument was manually tuned using perflurotributyl amine (PFTBA). The GC temperature program was started at $60^{\circ} \mathrm{C}$ then elevated to $280^{\circ} \mathrm{C}$ at rate of $8^{\circ} \mathrm{C} / \mathrm{min}$, and $10 \mathrm{~min}$ hold at $280^{\circ} \mathrm{C}$. The Detector and injector temperature were set at $280^{\circ} \mathrm{C}$ and $250^{\circ} \mathrm{C}$, respectively. Wiley and Nist 05 mass spectral database was used in the identification of the separated peaks.

\section{Statistical analysis:}

Completely randomized design in factorial arrangement with three replicates. according to Gomez and Gomez, 1984 was used. The least significant difference (L.S.D) between means was checked according to (Waller and Duncan 1969).

\section{RESULTS}

\section{Antifungal potential of PPE:}

The preliminary determination of the antifungal activity in vitro by using the poisoned food technique of the methanolic extract of pomegranate peel was studied against the six phytopathogenic fungal species: $B$. cinerea, C. dematium, F. oxysporum, F. solani, Phoma sp. and $R$. solani. The results (Table, 1) reveal variations in the antifungal activity of the methanolic extracts, that extract displayed high inhibitory effect on the growth of $B$. cinerea, F. oxysporum, F. solani, Phoma spp, C. dematium and R. solani, at concentrations from ranging between 1000 to 4000 ppm.

The in vitro antifungal activity of PPE expressed as a minimum effective concentration $\left(\mathrm{EC}_{50}\right)$ of $50 \%$ of mycelial growth with the corresponding $95 \%$ Confidence limits is shown in Table (2). It is clear that the antifungal activity increased with increasing the concentrations of the extracts. F. solani and C. dematium showed greater sensitivity to MPE than Phoma spp, $R$. solani, B. cinerea and F. oxysporum. The $\mathrm{EC}_{50}$ of the tested phytopathogenic fungi was 266.40, 272.47, 305.59, 307.88, 318.36 and $787.41 \mathrm{ppm}$, respectively. 
Table (1) Screening inhibitory potential of PPE at different concentrations on linear growth of six fungi.

\begin{tabular}{|l|c|c|c|c|c|c|}
\hline \multirow{2}{*}{$\begin{array}{l}\text { Concentration } \\
\text { (ppm) }\end{array}$} & \multicolumn{7}{|c|}{\begin{tabular}{c} 
Tested fungi \\
Percentage of Inhibition\% \\
\cline { 2 - 7 }
\end{tabular}} & $\begin{array}{c}\boldsymbol{B} \text {. } \\
\text { cineara }\end{array}$ & $\begin{array}{c}\boldsymbol{C} \text {. } \\
\text { dematium } \\
\text { oxysporum f. } \\
\text { sp. } \\
\text { lycopersici }\end{array}$ & F. solani & Phoma spp & $\begin{array}{c}\boldsymbol{R} . \\
\text { solani }\end{array}$ \\
\hline Control & 0.0 & 0.0 & 0.0 & 0.0 & 0.0 & 0.0 \\
\hline 31.3 & 16.0 & 20.9 & 7.7 & 7.70 & 13.7 & 21.8 \\
\hline 62.5 & 24.1 & 29.1 & 13.2 & 16.7 & 22.3 & 29.3 \\
\hline 125 & 44.1 & 38.5 & 20.9 & 30.7 & 33.4 & 37.9 \\
\hline 250 & 49.6 & 48.7 & 30.7 & 48.3 & 46.2 & 47.2 \\
\hline 500 & 55.2 & 58.9 & 42.1 & 66.3 & 59.3 & 56.6 \\
\hline 1000 & 66.3 & 68.6 & 54.2 & 81.1 & 71.5 & 65.6 \\
\hline 2000 & 72.6 & 77.1 & 65.9 & 90.0 & 81.6 & 73.8 \\
\hline 4000 & 83.0 & 84.2 & 76.3 & 90.0 & 89.1 & 80.9 \\
\hline LSD $\geq 0.05$ & 0.9 & 1.5 & 1.3 & 1.4 & 1.3 & 0.9 \\
\hline
\end{tabular}

Table (2) Effective concentration $\left(\mathrm{EC}_{50}\right)$ of $50 \%$ of the mycelial growth of six pathogenic fungi.

\begin{tabular}{|l|c|c|c|}
\hline \multirow{2}{*}{ Tested Fungi } & \multirow{2}{*}{$\mathbf{E C}_{\mathbf{5 0}}$} & \multicolumn{2}{|c|}{$\mathbf{9 5}$ \% Confidence limit } \\
\cline { 3 - 4 } & & Lower & Upper \\
\hline B. cinerea & 318.36 & 240.4 & 419.4 \\
\hline C. dematium & 272.47 & 207.6 & 353.3 \\
\hline F. oxysporum & 787.41 & 340.7 & 2998.4 \\
\hline F. solani & 266.40 & 194.2 & 361.3 \\
\hline Phoma sp & 305.59 & 186.1 & 491.8 \\
\hline R. solani & 307.88 & 281.3 & 336.7 \\
\hline
\end{tabular}

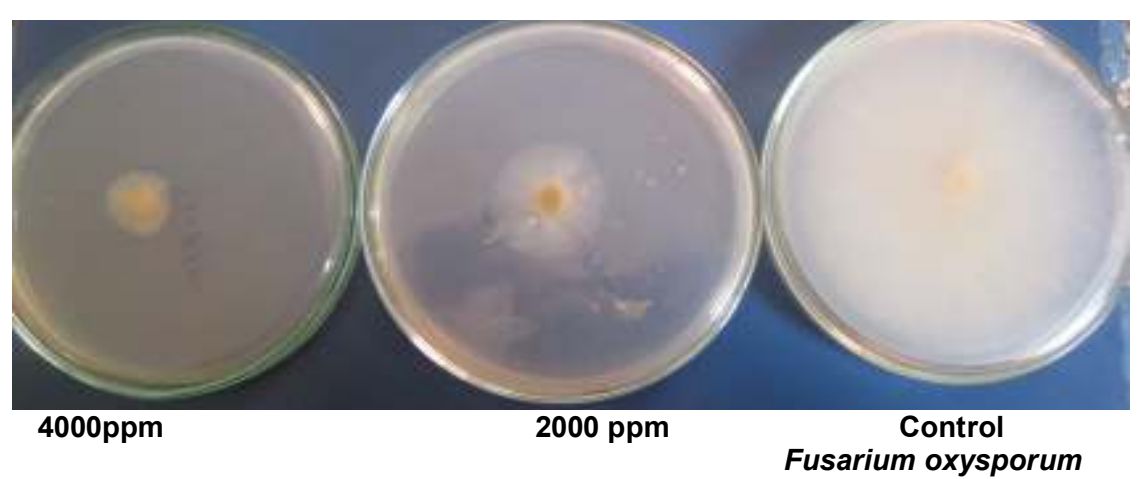

Fig. (1): Effect of different concentrations of PPE on the liner growth and spore germination of $F$. oxysporum $\mathrm{f}$. sp. lycopersici. 
Different concentrations of PPE were used to study their effect on the linear growth and spore germination of $F$. oxysporum $f$. sp. lycopersici. Data in Table (3) and Fig. (1) showed that PPE significantly decreased the linear growth and spore germination of $F$. oxysporum $\mathrm{f}$. sp. lycopersici compared to untreated control. Increasing the concentration was associated with an additional decrease with maximum records for linear growth and spore germination inhibition (s) at 4000 ppm, being 76.6 and $82.6 \%$ respectively.

Table (3):- Effect of different concentrations of PPE on the linear growth and spore germination of $F$. oxysporum $\mathrm{f}$. sp. lycopersici.

\begin{tabular}{|l|c|c|c|c|}
\hline $\begin{array}{l}\text { Concentration } \\
(\mathbf{p p m})\end{array}$ & $\begin{array}{c}\text { Linear } \\
\text { growth } \mathbf{( c m )}\end{array}$ & $\begin{array}{c}\text { Inhibition } \\
\mathbf{( \% )}\end{array}$ & $\begin{array}{c}\text { Spore } \\
\text { germination (\%) }\end{array}$ & $\begin{array}{c}\text { Inhibition } \\
\mathbf{( \% )}\end{array}$ \\
\hline 0.0 & 9.0 & - & 91.4 & - \\
\hline 250 & 6.3 & 30.0 & 69.4 & 24.1 \\
\hline 500 & 5.2 & 42.2 & 60.8 & 33.4 \\
\hline 1000 & 4.1 & 54.4 & 56.7 & 37.9 \\
\hline 2000 & 3.1 & 65.5 & 32.2 & 64.7 \\
\hline 4000 & 2.1 & 76.7 & 15.8 & 82.7 \\
\hline LSD $\geq 0.05$ & 1.9 & - & 14.6 & - \\
\hline
\end{tabular}

Effect of tomato seed application and soil treatment with peel powder on pre and post- emergence damping off caused by $F$. oxysporum f. sp. lycopersici.

Data presented in Table (4) show that application of pomegranate peel powder and the fungicide Flowsan significantly decreased damping-off and recorded the highest survivals and the lowest damping-off and the highest efficiency, being 4.2 and $92.3 \%$ respectively. Soil treatment with pomegranate peel powder was more higher than seed treatment in reducion. The efficiency of damping-off being $76.9 \%$ and $46.1 \%$, respectively.

Table (4) Effect of tomato seed application and soil treatment with peel powder on pre and post- emergence damping off caused by $F$. oxysporum f. sp. lycopersici.

\begin{tabular}{|c|c|c|c|c|}
\hline \multirow[b]{2}{*}{ Treatments } & \multicolumn{2}{|c|}{ Damping off (\%) } & \multirow[b]{2}{*}{$\begin{array}{c}\text { Total } \\
(\%)\end{array}$} & \multirow[b]{2}{*}{$\begin{array}{c}\text { Efficiency } \\
(\%)\end{array}$} \\
\hline & $\begin{array}{c}\text { Pre- } \\
\text { emergance }\end{array}$ & $\begin{array}{c}\text { Post- } \\
\text { emergence }\end{array}$ & & \\
\hline Seed treatment & $12.5 a^{*}$ & $16.7 a b$ & 29.2 & 46.1 \\
\hline Soil treatment & $8.3 a$ & $4.2 b$ & 12.5 & 76.9 \\
\hline $\begin{array}{l}\text { Fungicide } \\
\text { (Flowsan) }\end{array}$ & $0.0 a$ & $4.2 b$ & 4.2 & 92.3 \\
\hline Control & $20.8 a$ & $33.3 a$ & 54.2 & - \\
\hline
\end{tabular}

${ }^{*}$ Means within the same column followed by the same letter are not significantly different according to Duncan's multiple range test $(P \geq 0.05)$. 
Effect of seedling treatment and soil treatment with pomegranate peel extract before transplanting on disease incidence of tomato.

Data presented in Table (5) indicate that the used treatments significantly decreased disease incidence compared to untreated control. The fungicide treatment recorded maximum decrease $(4.2 \%)$ followed by soil treatment with PPE (8.3\%). Whereas, seedling treatment with the same extract gave the lowest effect, being $20.8 \%$.

Table (5):- Effect of seedling treatment and soil treatment with pomegranate peel extract before transplanting on disease incidence of tomato.

\begin{tabular}{|l|c|c|}
\hline Treatments & Disease incidence (\%) & Efficiency (\%) \\
\hline Seedling treatment & $20.8 b^{*}$ & 58.3 \\
\hline Soil treatment & $8.3 \mathrm{~b}$ & 83.3 \\
\hline Fungicide (Rizolex T) & $4.2 \mathrm{~b}$ & 91.6 \\
\hline Control & $50.0 \mathrm{a}$ & - \\
\hline
\end{tabular}

${ }^{*}$ Means within the same column followed by the letters are significantly different according to Duncan s multiple range test $(P \geq 0.05)$.

\section{Preliminary phytochemical determination of PPE.}

Plants produce phytoalexins are considered as a defensive tool in response to microbial invasion. (Glazebrook and Ausubel, 1994).The Preliminary qualitative phytochemical analysis of methanolic extract of pomegranate peel extract was carried out for detection of secondary metabolites is presented in Table (6-A). The results indicate that the alkaloids and saponin were totally absent showing the negative test. Carbohydrates, reducing sugar, sterols, glycosides, phenolic compounds, tannins and flavonoids were found to be present by the qualitative test. The similar findings were also reported by (Prashanth et al., 2001; Hegde et al., 2012; Satheeh, 2012; Amina and Filali, 2013; Kannaiyan et al., 2013 and Uma et al., 2012). This indicating the methanolic extract of pomegranate peel is good source of secondary metabolites having an important role in metabolism.

Table (6-A). Determination of some phytochemical groups in PPE by different tests.

\begin{tabular}{|l|c|c|}
\hline Test & Phytochemical compound & Reaction \\
\hline Molish's test & Carbohydrates & + \\
\hline Benedict's test & Reducing sugar & + \\
\hline Mayer's test & Alkaloids & - \\
\hline Salkowski's test & Sterols & + \\
\hline Borntrager's test & Glycosides & - \\
\hline Froth's test & Saponins & + \\
\hline Ferric chloride test & Phenolic compounds & + \\
\hline Gelatin test & Tannins & + \\
\hline Lead acetate test & Flavonoids & + \\
\hline
\end{tabular}

+ Present

- Absent 


\section{GC-MS analysis of PPE:}

Qualitativ analysis of the methanol extract of pomegranate peel was done using GC-MS analysis led to identification number of compounds (Fig.1). The active principals with their retention time (RT), molecular formula, molecular weight and concentration in the methanol extract of pomegranate peel are presented in Table (6-B). Thirty components were detected in the methanol extract. 2-furancarboxaldehyde, 5-(hydroxymethyl)- was found to be the major component of the methanol extract with $39.71 \%$ of the total peak area followed by 5,5-oxy-dimethylene-bis (2-furldehyde) , 2furancarboxaldehyde, 2, 5-furandione,3-methyl-, propanedioic acid ethyl-, diethyl ester and 4H-pyran-4-one,3-hydroxy-2-methyl 11.77, 9.38, 6.66, 5.97 and $5.58 \%$, respectively. Figs. 2-7 showed the mass spectrum of the most abundant components of methanol extract of pomegranate peel.

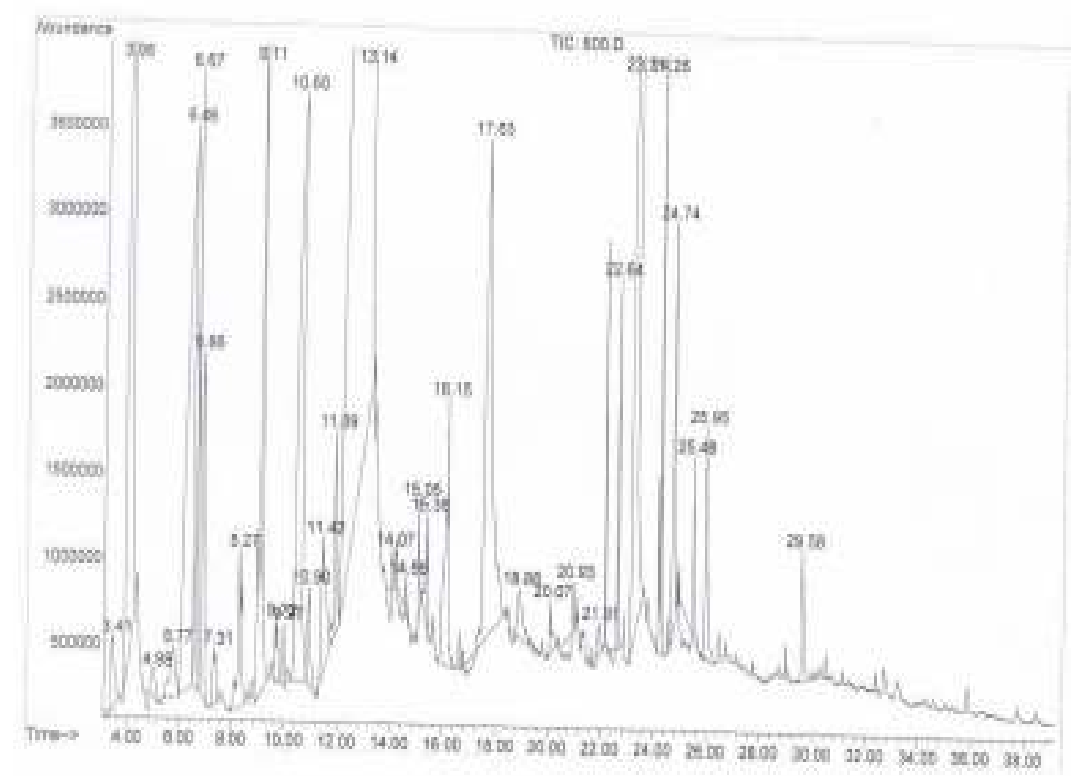

Figure 1. The chromatogram of all compounds produced from GC-MS analysis of methanolic extract of pomegranate peel.

Data presented in Tables (6-B) and Figs. (1-7) revealed that chemical analysis of methanolic extract of pomegranate peel contain many different compounds which have antifungal activities. These compounds including 5,5oxy-dimethylene-bis (2-furaldehyde), 9-Octadecanoic acid, and 2H-Pyran,3,4dihydro which belonged to Flavonids group, with average rate (13.87\%). 2Furancarboylic acid, methyl ester, 2-Thiophenacroxylic acid, 5-methyl, and 26-Pyridinediamine which belonged to Tannins group, with average rate (5.64\%).1H-Pyran-4-one,2,3-Dihydro 3-5-dihydroxy-6-methyl, $1 \mathrm{H}$-Indol-3- 
acetic acid,2-methyl, n-Hexadecanonic acid, and 3-Amino-S-triazole which belonged to phenolic group, with average rate $(4.52 \%)$. 1,3cyclohexanedione,2-methyl belonged to glycosides group, with rate of (1.10\%). 2,5-Furandione,3-methyl, propanedioic acid ethyl-,diethyl ester, $4 \mathrm{H}-$ pyran-4-one,2,3-dihydroxy-6-methyl, and 9-octadecanoic acid, methyl ester belonged to Sterols group, with average rate (19.85\%).

Table (6-B): The main components identified by GC-MS in the methanolic extract of Egyptian pomegranate peel.

\begin{tabular}{|c|c|c|c|c|c|}
\hline Peak & RT & Area\% & Name & $\begin{array}{c}\text { Molecular } \\
\text { Formula }\end{array}$ & $\begin{array}{c}\text { Molecular } \\
\text { Wight }\end{array}$ \\
\hline 1 & 3.41 & 0.53 & 3-Amino-S-triazole & $\mathrm{C}_{2} \mathrm{H}_{4} \mathrm{~N}_{4}$ & 84.04 \\
\hline 2 & 3.98 & 9.38 & 2-Furancarboxaldehyde & $\mathrm{C}_{5} \mathrm{H}_{4} \mathrm{O}_{2}$ & 96.02 \\
\hline 3 & 4.98 & 0.14 & $\begin{array}{l}\text { 4-cyclopentene-1,3-dione } 1 \mathrm{H} \text {-Imidazole,1- } \\
\text { ethyl- }\end{array}$ & $\mathrm{C}_{5} \mathrm{H}_{4} \mathrm{O}_{2}$ & 96.02 \\
\hline 4 & 5.77 & 0.6 & 2H-Pyran,3,4-dihydro- & $\mathrm{C}_{4} \mathrm{H}_{4} \mathrm{O}_{2}$ & 84.02 \\
\hline 5 & 6.46 & 6.66 & 2,5-Furandione,3-methyl- & $\mathrm{C}_{5} \mathrm{H}_{4} \mathrm{O}_{3}$ & 112.02 \\
\hline 6 & 6.67 & 1.48 & 2-Furancarboxaldehyde,5-methyl & $\mathrm{C}_{6} \mathrm{H}_{6} \mathrm{O}_{2}$ & 110.04 \\
\hline 7 & 6.86 & 1.65 & $\begin{array}{c}\text { 4H-pyran-4-one,2,3-Dihydro-3,5-dihydroxy- } \\
\text { 6- methyl- }\end{array}$ & $\mathrm{C}_{6} \mathrm{H}_{8} \mathrm{O}_{4}$ & 144.04 \\
\hline 8 & 7.31 & 0.37 & $\begin{array}{l}\text { ( s) -( - )-4-hydroxy-2-methyl-2- } \\
\text { cyclopentenone }\end{array}$ & $\mathrm{C}_{6} \mathrm{H}_{8} \mathrm{O}_{2}$ & 112.05 \\
\hline 9 & 8.27 & 1.10 & 1,3-cyclohexanedione,2-methyl- & $\mathrm{C}_{7} \mathrm{H}_{10} \mathrm{O}_{2}$ & 126.07 \\
\hline 10 & 9.11 & 3.59 & 2-Furancarboylic acid, methyl ester & $\mathrm{C}_{6} \mathrm{H}_{6} \mathrm{O}_{3}$ & 126.03 \\
\hline 11 & 9.72 & 0.36 & 4H-pyran-4-one,3-hydroxy-2-methyl & $\mathrm{C}_{6} \mathrm{H}_{8} \mathrm{O}_{2}$ & 112.05 \\
\hline 12 & 9.97 & 0.2 & $\begin{array}{c}\text { Butanoic acid,3-methyl-,2-methyl propyl } \\
\text { ester }\end{array}$ & $\mathrm{C}_{9} \mathrm{H}_{18} \mathrm{O}_{2}$ & 158.13 \\
\hline 13 & 10.6 & 5.58 & $\begin{array}{c}\text { 4H-pyran-4-one, } \\
\text { 2,3-dihydro-3,5-dihydroxy- } \\
6 \text { - methyl }\end{array}$ & $\mathrm{C}_{6} \mathrm{H}_{8} \mathrm{O}_{4}$ & 144.04 \\
\hline 14 & 11.42 & 1.09 & 2-Thiophenacroxylic acid,5-methyl & $\mathrm{C}_{6} \mathrm{H}_{6} \mathrm{O}_{2} \mathrm{~S}$ & 142.01 \\
\hline 15 & 11.89 & 0.93 & 5-formyl -2-furfuryl methanoate & $\mathrm{C}_{7} \mathrm{H}_{6} \mathrm{O}_{4}$ & 154.03 \\
\hline 16 & 13.14 & 39.71 & 2-Furancarboxaldehyde, 5-(hydroxymethyl)- & $\mathrm{C}_{6} \mathrm{H}_{6} \mathrm{O}_{3}$ & 126.03 \\
\hline 17 & 15.05 & 0.27 & Cyclopentanone,2-octyl- & $\mathrm{C}_{13} \mathrm{H}_{24} \mathrm{O}$ & 196.18 \\
\hline 18 & 15.36 & 0.37 & $\begin{array}{l}\text { 2,6-dimethyl cyclohexanone-5- } \\
\text { Acetoxymethyl-2-furaldehyde. }\end{array}$ & $\mathrm{C}_{8} \mathrm{H}_{14} \mathrm{O}$ & 126.10 \\
\hline 19 & 16.15 & 1.69 & 1H-Indol-3-acetic acid,2-methyl & $\mathrm{C}_{11} \mathrm{H}_{11} \mathrm{NO}_{2}$ & 189.08 \\
\hline 20 & 17.63 & 5.97 & Propanedioic acid ethyl-, diethyl ester & $\mathrm{C}_{9} \mathrm{H}_{16} \mathrm{O}_{4}$ & 188.10 \\
\hline 21 & 18.87 & 0.51 & Cyclohexane,1,2,4,5-tetraethyl cyclohexane & $\mathrm{C}_{14} \mathrm{H}_{28}$ & 196.22 \\
\hline 22 & 20.07 & 0.23 & Tetradecanoic acid & $\mathrm{C}_{14} \mathrm{H}_{28} \mathrm{O}_{2}$ & 228.37 \\
\hline 23 & 21.91 & 0.10 & 2-chloro-5-methoxybiphenyl & $\mathrm{C}_{13} \mathrm{H}_{11} \mathrm{Clo}$ & 218.05 \\
\hline 24 & 22.64 & 0.65 & n-Hexadecanoic acid & $\mathrm{C}_{16} \mathrm{H}_{32} \mathrm{O}_{2}$ & 256.424 \\
\hline 25 & 23.31 & 11.77 & 5,5-oxy-dimethylene-bis (2-furaldehyde) & $\mathrm{C}_{12} \mathrm{H}_{10} \mathrm{O}_{5}$ & 234.05 \\
\hline 26 & 24.26 & 1.64 & 9-Octadecanoic acid, methyl ester & $\mathrm{C}_{19} \mathrm{H}_{36} \mathrm{O}_{2}$ & 296.27 \\
\hline 27 & 24.74 & 1.50 & 9-Octadecanoic acid & $\mathrm{C}_{10} \mathrm{H}_{20} \mathrm{O}_{2}$ & 172.2464 \\
\hline 28 & 25.48 & 0.06 & $\begin{array}{c}\text { 3-Hydroxy-3-methoxycarbonyl-pentan } \\
\text { EDIOIC acid dimethyl ester }\end{array}$ & $\mathrm{C}_{9} \mathrm{H}_{14} \mathrm{O}_{7}$ & 7 \\
\hline 29 & 25.94 & 0.96 & 2,6-Pyridinediamine & $\mathrm{C}_{5} \mathrm{H}_{7} \mathrm{~N}_{3}$ & 109.06 \\
\hline 30 & 29.58 & 0.51 & 2,2,9,9-Tetramthyl dec-5-ene-3,7-diyne & $\mathrm{C}_{14} \mathrm{H}_{2} \mathrm{O}$ & 188.16 \\
\hline
\end{tabular}




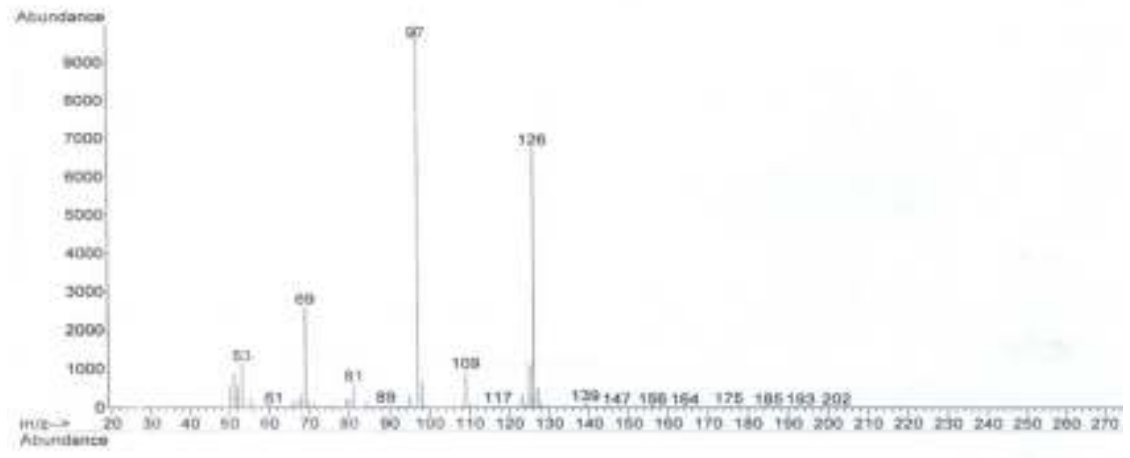

Fig. 2. Mass spectrum of 2-furancarboxaldehyde, 5-(hydroxymethyl).

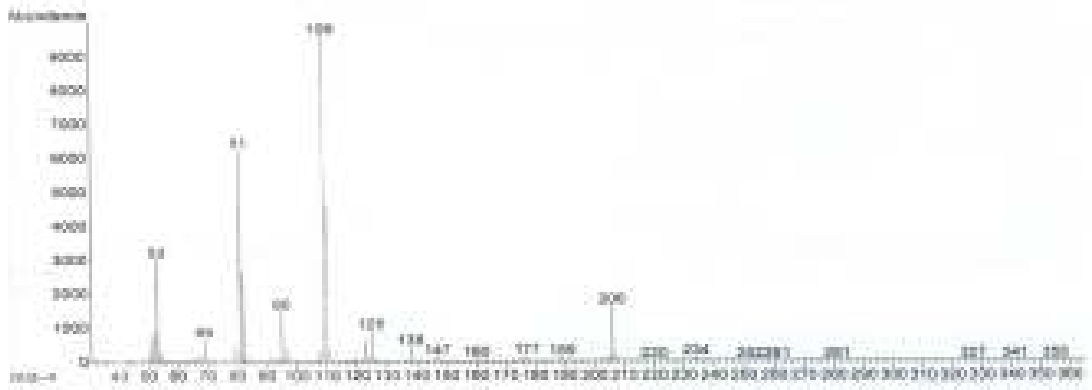

Fig. 3. Mass spectrum of 5,5-oxy-dimethylene-bis (2-furldehyde).

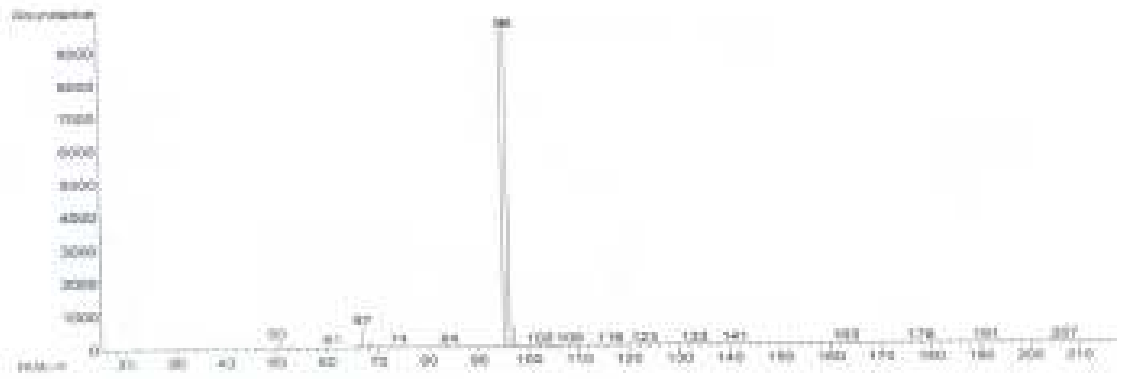

Fig. 4. Mass spectrum of 2-furancarboxaldehyde. 


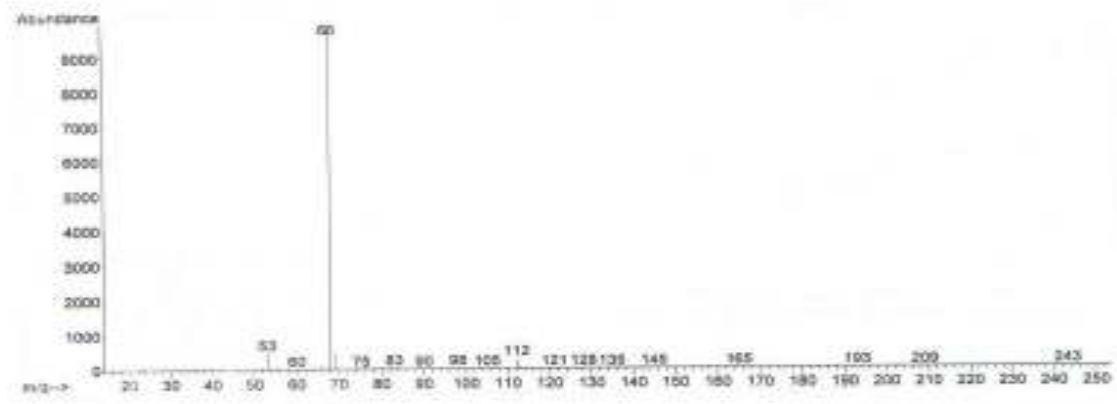

Fig. 5. Mass spectrum of 2, 5-furandione,3-methyl.

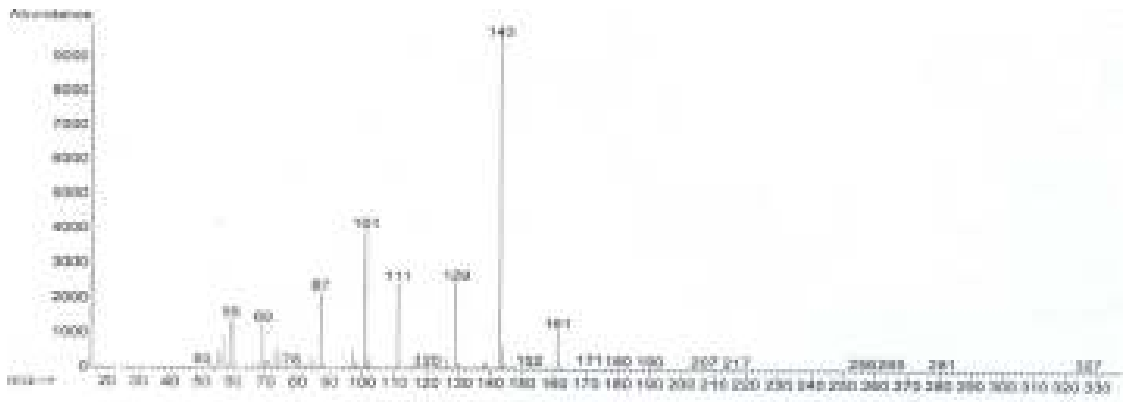

Fig. 6.Mass spectrum of propanedioic acid ethyl-, diethyl ester.

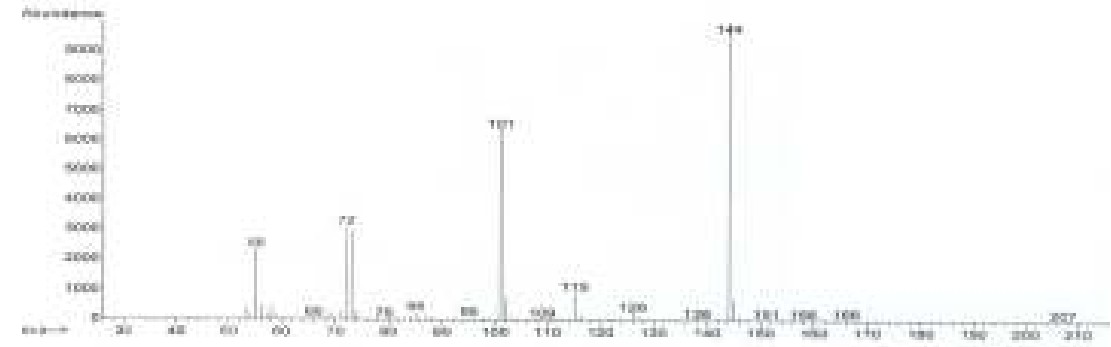

Fig. 7. Mass spectrum of 4H-pyran-4-one,3-hydroxy-2-methyl

\section{DISCUSSION}

In vitro obtained results indicated that pomegranate peel extract exhibited inhibitory effect on the linear growth of six phytopathogenic fungi isolated from different hosts, with minor variation among them. Furthermore, the tested extract effectively decrease the linear growth and spore germination of $F$. oxysporum (The causal of tomato damping off disease) and the maximum reduction was recorded at $4000 \mathrm{ppm}$. The presence of some 
phytocompounds in the pomegranate peel extract may be responsible for the inhibitory effect (Dahham et al., 2010). The antifungal activity of pomegranate extract against some phytopathogenic fungi have been previously reported by Dahham et al., 2010) who tested different pomegranate extracts on linear growth of different fungi. They found that the highest antifungal activity was recorded on Aspergillus niger followed by Penicillum citrinum and Rhizopus oryzae respectively.

Similarly, pomegranate extract reduced linear growth of Alternaria alternata, F. oxysporum, Phoma destructive, $R$. solani and Sclerotium rolfsii with different degrees of activity against the tested fungi (Al-Asker, 2012 and Mangang and Chhetry, 2012).

Under greenhouse conditions, application of pomegranate peel powder as seed treatment or soil application before sowing and transplanting tomato transplants in soil infested with $F$. oxysporum. $F$. oxysporum effectively decreased pre and post emergence damping-off compared to untreated infected control. At the same time, seedling treatment or soil treatment with pomegranate peel extract before sowing in soil infested with $F$. oxysporum provided good protection against disease incidence. Soil treatment was more effective than seedling treatment. Obtained results are in agreement with those reported by Satish et al., (2007), who found antifungal activity against seed-borne pathogens of Aspergillus spp as the result of application pomegranate peel extract. Also, pronounced decrease was found in citrus green mould disease (Penicillium digitatum) as a result of application of pomegranate peel extract Tayel et al., 2009. In another study, soil treatment with pomegranate leaf extract before sowing, effectively reduced root rot disease of French bean caused by Rhizoctonia solani, under greenhouse and field conditions.

Phytochemical analysis of PPE revealed that the extract containing different compounds including three flavonoids, four phenolic compounds, three tannins and one glycosides. These compounds were reported to have antimicrobial activities.

Several phenolic compounds are directly antifungal in vitro. For example, phenolic compounds extracted from olive plants showed antifungal activity against Phytophthora spp. in vitro. Also 4-O-glucoside and 7-Oglucoside completely inhibited conidial germination of Nurospora crassa (Lattanzio et al., 2006). Furthermore, phenolic compounds might have a major role to play in disease resistance through the inactivation of fungal cell wall degrading enzymes (cellulose and pectin methyl esterase), thereby restricting the degradation of the cell wall and the process of fungal invation in plant (Mandavia et al., 1999).

As for tannins, In vitro toxicity of tannins is well documented for several fungi including B. cinerea, A. niger, C. graminicola and Penicillum $\mathrm{sp}$ (Lattanzio et al., 2006). Furthermore, tannic acid exhibited antimicrobial activity against $A$. niger, $A$. fumigatus, $A$. flavus, $P$. granulatum and $P$. granulosum at concentration $3 \%$. This indicating the methanolic extract of pomegranate peel is good source of secondary metabolites having an important role. 
The present work refers to the possible use of agriculture waste as antimicrobial agents against phytopathogeny to overcome pesticide pollution and maintaining environment safety.

ACKNOWLEDGEMENT

The authors are thankful to Dr. Islam. N.Nasr (Central Agricultural Pesticides Laboratory) for helping in (GC-MS) analysis.

\section{REFERENCES}

Abdel-Kader, M. M; El-Mougy, N. S; Aly, M.D.E and Lashin, S.M. (2012). Integration of Biological and fungicidal alternatives for controlling foliar diseases of vegetables under greenhouse conditions. International Journal of Agriculture and forestry. 2(2):38-48.

Agarwal, M., Walia, S., Dhingra, S., Khambay, B.P.S. (2001). Insect growth inhibition, antifeedant and antifungal activity of compounds isolated/derived from Zingiber offcinale Roscoe (ginger) rhizomes. Pest Manage. Sci. 57, 289-300.

Al-Askar, A.A. (2012). In vitro antifungal activity of three Saudi plant extracts against some phytopathogenic fungi. Journal of Plant Protection Research. 52(4)458-462.

Asogwa, E.U., Ndubuaku, T.C.N., Ugwu, J.A., Awe, O.O. (2010). Prospects of botanicalpesticides from neem, Azadirachta indica for routine protection of cocoa farmsagainst the brown cocoa mirid Sahlbergella singularis in Nigeria. J. Med. PlantsRes. 4, 1-6.

Bajpai, V.K., Cho, M.J., Kang, S.C. (2010). Control of plant pathogenic bacteria of Xan-thomonas spp. by the essential oil and extracts of Metasequoia glyptostroboidesMiki ex $\mathrm{Hu}$ in vitro and in vivo. J. Phytopathol. 158, 479-486.

Chebaibi, Amina and Fouzia Rhazi Filali (2013). Bactericidal activity and phytochemical Comparative Evaluation Of Anti Microbial Activity Of Punica granatum Leaves Extracts Journal Of Medicinal Plants Research . Vol. 7(14), pp. 887-891.

Dahham, S.S; Ali, M.N; Tabassum, H and Khan, M. (2010). Studies on antibacterial and antifungal activity of Pomegranate (Puncia granatum L.) American-Eurasian J. Agric. \& Environ. Sci., 9(3):273-281.

Evans W.C. 1997. An index of medicinal plants. A text book of pharacognosy, vol 7(5), $14^{\text {th }}$ Edn, pp 12-14.

Field, B., Jorden, F., Osbourn, A. (2006). First encounters-deployment of defenserelated natural products by plants. New Phytol. 172, 193-207.

Glazebrook J. and Ausubel F.M., (1994). Isolation of phytoalexin-deficient mutants of Arabidopsis thaliana and characterization of their interactions with bacterial pathogens, Proc. Natl. Acad. Sci. USA, 91(19), 8955- 8959

Gomez, K.A. and Gomez, A.A. (1984). Statistical Procedures for Agricultural Research. John Wiley and Sons, NY, USA. 680pp. 
Hegde, C, R., M. Madhuri, Swaroop T. Nishitha, Das Arijit1, Bhattacharya Sourav and K.C. Rohit (2012): Evaluation of Antimicrobial Properties, Phytochemical Contents and Antioxidant Capacities of Leaf Extracts of Punica granatum L. ISCA Journal of Biological Sciences. Vol. 1(2), 3237.

Kannaiyan, M., Thambidurai, P., Raja, V., Belli T, S., Ponnusamy, V and Nooruddin, T. (2013). Antimicrobial activity and qualitative phytochemical analysis of Punica granatum Linn. (PERICARP): Journal of Medicinal Plants Research Vol. 7(9), 474-479.

Kokate C.K., 1999. Practical Pharmacognosy, (4th Edn), Vallabh Prakashan Publication, New Delhi, India.

Kordali, S., Cakir, A., Zengin, H., Duru, M.E. (2003). Antifungal activities of the leaves of three Pistacia species grown in Turkey. Fitoterapia 74, 164-167

Kosalec, I; Pepeljnjak, S; Bakmaz, M and knezevic S. V. (2005). Flavonoid analysis and antimicrobial activity of commercially available propolis products. Acta Pharma. 55, 423-430.

Lattanzio, V; Veronica, M., Lattenzio, T. and Cardinali, A. (2006). Role of phenolic in the resistance mechanisms of plant against fungal pathogens and insects. Phytochemistry: Advances in Research: 23-67. Editor: Filippo imperator- kerala, India.

Lee, H.S. (2007). Fungicidal property of active component derived from Acorus gramineus rhizome against phytopathogenic fungi. Bioresour. Technol. 98, 1324-1328.

Mace M.E. (1963). Histochemical localization of phenols in healthy and diseased tomato roots, Phytochem. 16, 915-925.

Mangang, H.C and Chhetry, G.K.N. (2012). Antifungal properties of certain plant extracts against Rhizoctonia solani causing root rot of franch bean in organic soil of Manipur. International Journal of Scientific and Research Publications, volume 2,Issue 5.1-4.

Nunez, Y.O., Salabarria, I.S., Collado, I.G., Hernandez-Galan, R. (2006). The antifungal activity of widdrol and its biotransformation by Colletotrichum gloeosporioides

Ojala, T., Remes, S., Haansuu, P., Vuorela, H., Hiltunen, R., Haahtela, K., Vuorela, P. ( 2000). Antimicrobial activity of some coumarin containing herbal plants growing in Finland. J. Ethnopharmacol. 73, 299-305.

Prakash, A., Rao, J., Nandagopal, V. (2008). Future of botanical pesticides in rice, wheat, pulses and vegetables pest management. J. Biopest. 1, 154-169.

Prashanth, D.J., M.K. Asha and A. Amit, (2001). Antibacterial activityof punica granatum. Fitoterapia, 72:171-173.

Ramkrishnan S. and Rajan R., (1994). Text Book of Medical Biochemistry, Orient Longman, New Delhi, India pp715.

Satheesh, K, B., Suchetha, K, N., Vadisha, S. B, Sharmila, K.P., Mahesh, P, B (2012). Preliminary Phytochemical Screening Of Various Extracts of Punica granatum Peel, Whole Fruit and Seeds. Nujhs Vol. 2, No.4, 3438. 
Singh, P; Srivastava, B; Kumar, A; Kumar, R; Dubey, N.K and Gupta, R., (2008). Assessment of Pelargonium graveolens oil as plant-based antimicrobial and aflatoxin suppressor in food preservation. Journal of the Science of Food and Agriculture .88, 2421-2425.

Steffens, J. J; Pell, E.J; Tien, M.( 1996). Mechanisms of fungicide resistance in phytopathogenic fungi. Curr. Opin. Biotechnol. 7, 348-355.

Tampoare, G.B; Adazabra, A.N and Miller, G.K. (2013). Analyzing the economic benefit of fresh tomato production at the Tono irrigation scheme in upper east region of Ghana. Elixir Agriculture 58 (2013) 14613-14617

Tayel, A. A; Al-Baz A.F; Salem, M.F and El- Hadary, M.H. (2009). Potiential application of pomegranate Peel extracts for the control of citris green mould. J. Plant Diseases and Protection, 116(6):252-256.

Uma, M. R., Manasa, N., Chinna, E. M., Sindhura, S (2012). Comparative evaluation of antimicrobial activity of Punica Granatum Leaves Extracts IJPPDR / 2(2), 2012, 98-104.

Waller, R. A and Duncan, B. D. 1969. A way for the symmetric multiple comparison Problem. Amer .Stat.Assoc.J., 3:1485-1503.

$$
\begin{aligned}
& \text { تأثثير قثر الرمان على بعض الفطريـات الممرضة للنبات و مقاومـة مرض سقوط بـادرات } \\
& \text { الطماطم }
\end{aligned}
$$

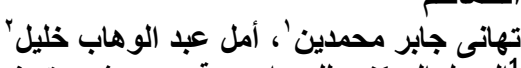

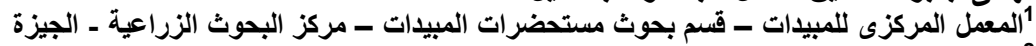

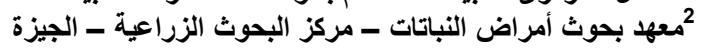

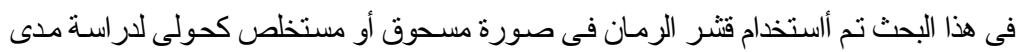

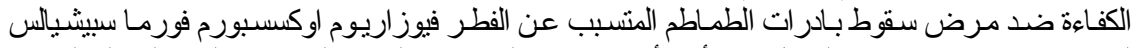

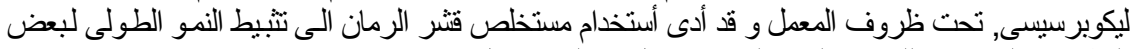

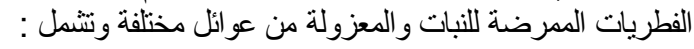

